\title{
SENI KRIYA \\ ANTARA TEKHNIK DAN EKSPRESI
}

\author{
Rispul *)
}

\begin{abstract}
The art craft is one of the traditional arts that could be used as an expression medium for anybody. With its capacity as an art filled of local genius, the art craft keep changing in every aspect, including on creating process and the medium has been used. Combination between technique and proper medium will create the art craft that capable to fulfill the world's need and demand. Craftsman capability to manage the medium, understanding it, created innovatively and to be able to see society's phenomenon will definitely generate responsibly work of art. Especially if they can took advantage of local genius that filled with sophisticated traditional value during their creating process, this will creates remarkable works of art craft which creative and innovative in a fresh form.
\end{abstract}

Keywords: Art craft, technique, expression

\section{Pendahuluan}

Berekspresi melalui karya seni merupakan salah satu kebutuhan manusia yang tergolong dalam kebutuhan akan keindahan. Kebutuhan ini muncul karena adanya dorongan dari dalam diri manusia yang secara hakiki senantiasa ingin merefleksikan keberadaannya sebagai mahluk yang bermoral, berakal dan berperasaan. Sebagai bagian dari hasil kebudayaan, karya seni, termasuk juga unsur-unsur kebudayaan lainnya terkait satu dengan lainnya secara fungsional dalam keseluruhan sistem. Karya kriya kaitannya dengan kebudayaan menjadi salah satu bentuk ekspresi (hasil-hasil prilaku) manusia yang berkaitan erat dengan pemenuhan kebutuhan primer, sekunder dan budaya (Tjetjep Rohendi Rohidi, 2002 : 6). Dalam karya kriya tercermin kegunaan bagi pemenuhan kelangsungan hidup manusia sehari-hari, identitas, dan integritas sosial, serta interaksi sosial yang melibatkan orang lain dalam pembuatan dan penikmatannya.

Karya kriya secara umum dipahami sebagai suatu karya yang dikerjakan dengan menggunakan alat sederhana, mengandalkan kecekatan tangan dan secara fungsional memiliki kegunaan untuk memenuhi kebutuhan sehari-hari. Karya kriya sangat kental merefleksikan lingkungan budaya dan geografis tempat karya itu diciptakan, artinya dalam seni kriya baik dalam proses dan teknik pembuatan, bentuk karya dan penggunaannya tercermin nilai-nilai estetika, etika dan logika.

Seni kriya merupakan jenis kesenian yang telah hidup lama pada kelompokkelompok masyarakat tradisional, hidup di kalangan berbagai suku bangsa yang lazim digunakan secara fungsional untuk memenuhi kebutuhan masyarakat pendukungnya. Sistem pewarisan keahlian itu dilakukan secara turun temurun sehingga dikategorikan sebagai seni tradisional (SP Gustami, 1997: 4)' yang tentu saja dalam proses perjalanannya terjadi perubahan-perubahan sesuai situasi dan kondisi masyarakat pendukungnya.

Dalam perkembangannya seni kriya menunjukkan adaptasinya pada perubahanperubahan yang terjadi. Pembuatan kriya

\footnotetext{
*) Rispul (rispul@ymail.com), Staf Pengajar Program Studi Kriya Seni, Jurusan Kriya, Fakultas Seni Rupa, Institut Seni Indonesia Yogyakarta.
} 
yang pada awalnya didorong atau didasarkan pada hasrat manusia atau kelompok untuk membuat alat-alat yang diperlukan dalam rangka pemenuhan kebutuhan primer demi menunjang kelangsungan hidupnya, kemudian berkembang menjadi pemenuhan kebutuhan sosial terjadinya interaksi antar manusia atau antar kelompok untuk memenuhi kebutuhannya berupa barang, dan kemudian juga menjadi pemenuhan kebutuhan budaya dalam hal penciptaan dan pemilikan karya seni kriya yang berkualitas/bermutu untuk kebanggaan dan martabat seseorang. Kualitas dan kuantitas dalam penciptaan seni kriya juga berkembang seirama dengan tuntutan dan perubahan sumber daya alam, fisik dan lingkungan serta perubahan-perubahan yang terjadi dalam nilai-nilai budaya.

Faktor yang menyebabkan terjadinya perubahan itu beraneka ragam, baik yang disebabkan oleh masyarakat itu sendiri atau pengaruh dari luar. Seperti halnya kegiatan reproduksi yang berkembang di samping bahan baku dan pendukung lainnya yang berlimpah sangat memungkinkan untuk menghasilkan bermacam-macam seni kriya. Seni kriya mulai berkembang setelah berkenalan dengan kebudayaan baru yang membawa pengaruh kesenian baru. (Bambang Suwondo,1979 : 24). Maksudnya dengan masuknya kebudayaan asing akan membawa pengaruh pada kesenian yang sudah ada, khususnya dalam hal ini seni kriya, sehingga melahirkan corak seni kriya dengan bentuk-bentuk baru yang lebih kreatif.

Banyak ahli dalam mengamati seni rupa khususnya seni kriya berpendapat yang memberikan pandangan dan bahasannya dalam mengartikan tentang seni kriya. SP. Gustami dalam bukunya, mengutip dari Cilvio dan Edmund Burke Feldman mengatakan bahwa: sementara pihak menafsirkan bahwa konsep kriya semakna dengan craft, yaitu cabang seni yang dipandang lebih mengutamakan ketrampilan tangan dari pada ekspresi, (SP. Gustami, 2000 : 264) yang melahirkan produk kriya yang bersifat pemenuhan kebutuhan spiritual keagamaan dan kebutuhan fungsional praktis yang dalam proses perwujudannya dikerjakan dengan keterampilan tangan dan teknik yang tinggi, bahkan tidak jarang juga diberi hiasan tertentu sesuai dengan kegunaan produk kriya tersebut dalam suatu masyarakat. Mengenai kaitan antara kebutuhan spiritual dan fungsional, SP. Gustami mengatakan:

Dengan masuknya pengaruh Hindu membawa era sejarah baru bagi masyarakat Indonesia. Pengenalan struktur pemerintahan kerajaan berdasarkan sistem kasta menimbulkan strata kehidupan dari golongan rakyat jelata sampai pada tingkat bangsawan dan raja serta kaum rohaniawan, golongan brahma. Masing-masing strata menentukan produk kriya, mulai dari keperluan hidup sehari-hari sampai pada kebutuhan yang menyangkut segisegi spiritual keagamaan bahkan raja dianggap dan dikukuhkan sebagai titisan dewa maka segala sesuatu yang diperuntukkan bagi raja dibuat sebaikbaiknya dengan penuh kerelaan dan pengabdian. (SP.Gustami, 1990 : 3)

Seni kriya secara turun temurun tetap dibutuhkan guna memenuhi fungsi praktis di kalangan masyarakat luas, walaupun produk seni kriya masa lampau memiliki kegunaan praktis tertentu, namun nilai estetis, simbolis, dan spiritualnya luluh bahkan terkadang berada pada fungsi fisiknya (SP.Gustami, 1991 : 4). Lain halnya dengan produk kerajinan, seperti tepas, cowek dan sejenisnya, sangat ditentukan oleh fungsi praktisnya, kenyamanan dipakai, dan bentuknya sesuai dengan kegunaan masing-masing. 
Pada awalnya seni kriya lahir karena tuntutan kebutuhan manusia dalam menunjang aktivitas kehidupannya seharihari, namun sesuai dengan berkembangnya pola pikir manusia, seni kriya pun berkembang menjadi objek untuk berkreativitas, sesuai dengan yang pernah diungkapkan oleh But Muchtar:

Kriya mulai diciptakan untuk memenuhi kebutuhan pokok dalam kehidupan dan karenanya dikatakan mempunyai fungsi. Sejak jaman batu, manusia mendisain barang praktis umpamanya sebuah kapak, alat sederhana ini dibawanya setiap hari sebagai alat serba guna. Bahwa manusia tidak kurang cerdas dari manusia jaman kini dapat dibuktikan dari perkembangan disain kapak yang beraneka ragam, yang dapat disaksikan di museum, nenek moyang Indonesia telah mendisain kapak batu mereka dalam suatu proses kreatif yang menghasilkan bentuk yang benilai. Nilai tersebut tidak semata-mata terletak pada bentuk visual, tetapi pada prinsipnya terjadi karena ada hubungan struktural dan fungsional sebagai sistem yang terpadu. Ekspresi pribadi kriyawan yang kadang disebut seniman, usahanya untuk melayani kebutuhan praktis manusia, serta kesadarannya sebagai anggota masyarakat dalam memenuhi kebutuhan spiritual, kesemuanya itu terpadukan dalam suatu objek yang disebut "kriya". Dengan demikian seorang kriyawan pada hakekatnya berguna dan merupakan komponen penting dalam kebudayaan bangsa.(But Muhtar, 1991 : 2-3).

Selanjutnya Imam Buchori Zaenuddin menyebutkan terdapat empat kategori dalam kriya: (Imam Buchari, 1999 : 1). yang pertama, adalah kriya yang tradisional yang konteknya budaya etnis; kategori kedua adalah kriya yang dibuat dalam konteks agama / kepercayaan; kategori ketiga, kriya yang disebut dengan kerajinan rakyat, dan kategori keempat adalah kriya yang dibuat oleh seniman atau disainer. Dalam perkembangannya kriya kategori yang keempat ternyata banyak sekali terlihat produk dengan kemasan baru yang telah dihasilkan semakin bervariasi dan ekpresif.

\section{Pengertian Seni Kriya}

Pengertian seni kriya sampai saat ini masih sering menjadi bahan diskusi yang tak habis-habisnya dibahas. Terdapat beberapa pendapat yang bermacam-macam, hal ini dapat dimaklumi mengingat masing-masing pendapat memiliki cakrawala pandang yang berangkat dari garis pijak, sudut pandang pendekatan dan kajian yang tidak selalu sama. Dalam kamus Bausastra Jawa-Indonesia kata "Kriya" berarti pekerjaan atau kerajinan tangan. Penjelasan berikutnya oleh Soedarso Sp. dalam bukunya dituliskan bahwa seni kriya adalah cabang seni rupa yang sangat memerlukan kekriyaan (craftmanship) yang tinggi seperti misalnya ukir kayu, seni keramik, anyam-anyaman, dsb. (Soedarso Sp., 1990 : 15). Sedangkan arti craftman adalah seniman yang memiliki ketramplian teknik.

Dalam bahasa sangsekerta istilah "kriya" berasal dari akar kata "kr" yang berarti mengerjakan, dari akar kata tersebut kemudian menjadi kata: karya, kriya, kerja. Dalam arti khusus adalah mengerjakan sesuatu untuk menghasilkan benda atau objek. Pengertian berikutnya semua hasil pekerjaan termasuk berbagai ragam tekniknya disebut "seni kriya".(Timbul Haryono, 2002 : 1) Dalam bahasa Indonesia kata "kriya" berarti pekerjaan (kerajinan tangan). Di dalam bahasa Inggris disebut craft yang berarti energi atau kekuatan. Kemudian istilah itu diartikan sebagai ketrampilan dan dikaitkan dengan sebuah profesi seperti yang terlihat dalam craftsworker (pengerajin). Pada kenyataannya bahwa seni kriya sering 
dimaksudkan sebagai karya yang dihasilkan karena skill atau ketrampilan. (Made Bandem 2002: 1).

SP. Gustami menjelaskan sebagai berikut:

Bahwa yang dimaksud seni kriya dalam bahasan ini ialah suatu karya seni yang unik dan karakteristik yang didalamnya mengandung muatan nilalnilai yang mantap dan mendalam menyangkut nilai estetik, simbolik, filosofis, dan fungsinya. Oleh karena itu di dalam perwujudannya di dukung "craftsmanship" tinggi, akibat nya kehadiran seni kriya termasuk dalam kelompok seni-seni "adiluhung"... selanjutnya seni kriya pada masa lampau itu, sekarang mendapat predikat sebagai seni-seni tradisional.( SP.Gustami, 1992 : 71).

Lebih lanjut diungkapkan oleh SP. Gustami sebagai berikut:

Istilah kriya dan kerajinan dilahirkan dari terjadinya stratifikasi sosial yang telah mengantarkan dualisme budaya dalam masyarakat, budaya agung dalam "tradisi besar" berkembang di dalam tembok Kraton di kalangan kaum bangsawan. Sedangkan budaya alit dalam "tradisi kecil" berkembang di luar tembok Kraton. Istilah kriya lahir dari tradisi besar untuk menyebut hasil karya seni yang dihasilkan oleh abdi dalem kriya (Kriyawan). Sedangkan istilah kerajinan untuk menyebut hasil karya para perajin yang lahir dari tradisi kecil, sedangkan tempat melakukan kegiatan disebut "desa kerajinan", oleh karenanya istilah ini lebih memasyarakat. (SP.Gustami, 1991 : 98).

Sesungguhnya ada perbedaan istilah antara seni kriya dan kerajinan yang memiliki latar belakang yang tidak jauh berbeda, terutama dalam nilai-nilai yang menyangkut segi kualitas dari penghayatan terhadap cita rasa estetik serta filosofi dan simbol-simbol ekspresi, dan mengandung muatan nilai-nilai yang lebih dalam dan sesuai dengan fungsinya yang menyangkut segi-segi ritual dan simbol status, penampilannya bahkan lebih sempurna dan adiluhung, diantaranya mencapai tingkat klasik. Sebaliknya pada seni kerajinan, yang meskipun acap kali mempunyai fungsi fisik yang sama, tetapi perhatian terhadap muatan tadi sangat berkurang. Bentuk perwujudannya berkesan wantah, datar, dangkal, dan tidak bermakna, bahkan sering kali tarnpak kasar dan tidak selesai. Dalam perkembangan lebih lanjut menjadi seni-seni tradisional yang secara turun-temurun tetap diperlukan, guna memenuhi fungsi-fungsi praktis di kalangan masyarakat luas.(SP.Gustami, 1997 : 353).

Berdasarkan beberapa pengertian di atas, maka disimpulkan bahwa pengertian seni kriya merupakan sesuatu yang dikerjakan dengan kecendrungan lebih banyak melibatkan kemampuan dan keahlian yang dihasilkan oleh tangan terampil, bersifat dekoratif serta dalam visualisasinya dibuat dengan sangat artistik walaupun seringkali merupakan produk yang memiliki fungsi praktis (berguna). Hal ini sejalan dengan yang dikemukan Soedarso Sp bahwa Kriya atau crafts atau handicrafts adalah (1) sesuatu yang dibuat dengan tangan, dengan kekriyaan yang tinggi, (2) umumnya dibuat dengan sangat dekoratif atau secara visual sangat indah, dan (3) sering kali merupakan barang guna (Soedarso, 2006 : 107).

$$
\begin{aligned}
& \text { Seni kriya berkaitan dengan } \\
& \text { pemenuhan fungsi-fungsi tertentu, } \\
& \text { meskipun pemenuhan fungsi-fungsi itu } \\
& \text { sering dipandang hanya dari sisi fisiknya saja } \\
& \text { tidak menyeluruh, tidak sesuai dengan } \\
& \text { realitas kebutuhan hidup yang lengkap dan } \\
& \text { utuh, kebutuhan jasmani dan rohani. Fungsi } \\
& \text { seni dapat dikelompokkan ke dalam tiga } \\
& \text { kategori yaitu fungsi personal, fungsi sosial } \\
& \text { dan fungsi fisik. (SP. Gustami, 2002: 1). }
\end{aligned}
$$


Fungsi personal berkaitan dengan pemenuhan kepuasan jiwa pribadi atau individu. Fungsi sosial berhubungan dengan tujuan-tujuan sosial, ekonomi, politik, budaya dan kepercayaan. Sedangkan fungsi fisik berurusan dengan pemenuhan kebutuhan praktis. Dalam perwujudannya, ketiga fungsi seni itu seringkali saling bergayut sebagai satu kesatuan yang utuh dan padu.

Seni kriya tidak akan pernah dihargai masyarakatnya jika didalamnya tidak disertai faktor kreativitas, inovatif, unik sebagai hasil eksplorasi bentuk-bentuk baru yang menarik, bukan sekedar mengandalkan nilai guna atau ketrampilan semata atau sekedar mengandalkan eksploitasi motif-motif ornamental yang mentradisi (mengulang-ulang kaidah seni lama) yang monoton dan statis.

Seni kriya dalam penciptaannya sangat membutuhkan kekriyaan (craftsmanship) yang tinggi, ketangkasan tekhnik (virtuositas) dari pembuatnya, maka sesuai dengan perubahan dan perkembangan zaman, bahwa penciptaan seni kriya pada saat ini tidak hanya mengarah pada produk seni kriya yang memenuhi kebutuhan praktis, tetapi penciptaan seni kriya juga telah banyak mengarah pada tujuan-tujuan ekspresi pribadi. Sesungguhnya perkembangan itu merupakan suatu realitas yang terjadi atas dasar kebebasan berkreasi dan berekspresi, sejalan dengan perubahan situasi dan kondisi masyarakat.

\section{Pengertian Tekhnik}

Interaksi antara pribadi seniman/kriyawan dengan sarana akan membuahkan apa yang disebut dengan istilah keterampilan, craftsmanship (skill), untuk menguasai kemampuan tekhnik ini bisa dicapai dalam waktu yang relatif pendek atau panjang tergantung pada intensitas interaksi dan besar kecilnya bakat serta kecerdasan, ketekunan ditambah dengan faktor-faktor lingkungan dan kesempatan yang jelas berperan dalam menumbuhkan suatu bentuk keterampilan dan craftsmanship yang dikuasai oleh seniman. Kemampuan tehknik disini adalah suatu tata cara atau suatu pelaksanaan mengenai seluk beluk yang baku dalam mengerjakan karya seni, Soedarso Sp menjelaskan bahwa tehknik berasal dari bahasa Yunani "Techne" yaitu kemampuan untuk membuat atau mengerjakan sesuatu yang disertai pengertian yang betul-betul tentang prinsip- prinsipnya.(Soedarso Sp, 1990 : 16).

Dalam kamus umum Bahasa Indonesia disebutkan tentang pengertian teknik yaitu : cara (kepandaian dan sebagainya) membuat sesuatu (WJS Purwadarminta, 1974 : 16).

Dalam seni kriya dikenal adanya craftsmanship, yakni kemampuan keterampilan tangan, pengalaman teknis dan estetis, dengan penguasaan teknik ini semakin dapat memperluas khasanah berkreasi pada diri kriyawan, juga berpengaruh terhadap tingkat kesempurnaan karya, yakni tercipta sebuah karya kriya yang ngrawit, mgremit, werit, jlimet dan sophisticated.

\section{Pengertian Ekspresi}

Ekspresi sebagai unsur penting dari suatu karya seni, kehadirannya tidak dapat dipisahkan dari unsur keindahan, sebab keberadaannya nyata terlihat sebagai suatu penandaan tertinggi dari seuatu objek.(FX Mudji Sutrisno, 1993 : 142).

Ekspresi dalam pandangan awam disebut "ilham", namun dengan semakin majunya ilmu pengetahuan seni, konsep ekpresi ini kemudian bergeser ke pengertian baru. Ekspresi harus ditafsirkan secara lebih luas, tidak hanya terbatas pada pelampiasan emosi yang spontan (seperti dalam corak Ekpresionistik), tetapi getaran lembut yang keluar dari jiwa seseorang seniman harus pula diterima sebagai wujud ekspresi. Sarana untuk berekpresi dalam 
seni tidaklah bersifat instingtif, juga tidak stereotip. la (Ekspresi) harus dicari, sebab sangat terkait dengan teknik pengerjaan sebuah karya seni, karena itu untuk dapat berekspresi dengan leluasa justru diperlukan teknik yang tinggi.(Soedarso, 1990 : 45-46).

Lebih lanjut Soedarso Sp. dalam seni dan keindahan bahwa :

Keseriusan dan ketekunan seniman dalam menggarap karyanya itu sangat penting artinya. Sebagai suatu ekpresi, sebuah karya perlu digeluti dan diperjuangkan dengan baik. Maka salah satu bahaya dari seseorang seniman yang virtuositasnya tinggi, adalah bahwa karyanya mudah sekali terasa dangkal, hanya berada di permukaan saja. (Soedarso 1998 : 29).

Suatu karya seni ekspresi yang kreatif dapat dikatakan sebagai suatu simbol yang terkomposisikan secara kreatif estetis, karya seni dapat dikatakan sebagai "simbol jati diri" dalam konteks human social life. Maka karya seni itu jelas memiliki prestige value yang sangat berarti bagi seniman dalam konteks human social reality_nya. (Ahmad Sadali, 1986 : 6-7).

Berdasarkan pendapat di atas dapatlah disimpulkan bahwa ekspresi adalah ungkapan perasaan, yang dalam pelampiasannya tidak hanya emosi spontan, tetapi juga getaran-getaran lembut yang keluar dari jiwa seseorang. Untuk mewujudkan ekspresi dalam karya seni, diperlukan kemampuan penguasaan teknik, keseriusan dan ketekunan seniman dalam menggarap karyanya.

\section{Tekhnik Dan Ekspresi Dalam Seni Kriya}

Membicarakan masalah ekspresi dalam seni kriya dalam perwujudannya tidak bisa secara spontan seperti halnya dalam lukisan. Namun sangat terkait dengan penguasaan teknik dan media ekspresi itu sendiri.
Seni kriya sebagai media ekspresi dalam perkembangannya sejalan dengan arus kemajuan jaman, mengingat konsep dasar yang melandasi penciptaannya, salah satunya adalah untuk memenuhi kebutuhan, kepuasan manusia, para kriyawan masa lampau menciptakan karya seni untuk memenuhi kebutuhan yang bersifat pribadi.

Seni kriya sebagai media ekspresi perkembangannya mempunyai ruang lingkup yang sangat terbuka, kebebasan, keleluasaan sesuai dengan cita rasa, kemampuan teknik, pengalaman estetik dan kedalaman ekspresi dari masing- masing kriyawan. Dari sekian banyak bahan yang menjadi pilihan seperti : kayu, logam, tanah liat, kulit, dan serat, para kriyawan dapat memanfaatkan sesuai dengan kemampuannya dalam memahami sifat sifat dan karakter bahan, juga kemauan dan kemampuan skill yang dimilikinya. Penggarapan tema pada seni kriya sangat bebas dalam arti memanfaatkan unsur unsur tradisi untuk diolah di sesuaikan dengan nuansa yang berkembang dewasa ini, yang memberi kebebasan berfikir, menangkap fenomina - fenomina yang berkembang dan kebebasan untuk mengekspresikannya, seni kriyapun berkembang mencari bentuk-bentuk baru, sebagai ungkapan ekspresi pribadi bagi kriyawannya.

Konsep kriya ekspresi masih perlu dihayati lebih dalam, kriya ekspresi adalah bentuk kriya masa kini yang cenderung meniru atau menyimpang dari norma tradisi yang berlaku. Atau secara sederhana menjadikan karya kriya itu kreatif, tidak sekedar ulangan dari bentuk-bentuk yang sudah ada.( SP.Gustami, 1991 : 183). Yang memperlihatkan bahwa cirri utama dari kriya ekspresi adalah bentuknya yang kreatif, menyimpang dari bentuk yang sudah ada, dalam arti mencari bentukbentuk baru, hal ini sesuai dengan ungkapkn Soedarso SP., bahwa : 
Seni modern justru mengejar novelty, mengejar yang baru, yang lain dari pada yang lain. Horizon seni modern tidak kenal batas, kecuali batas kemampuan imajinasi senimannya. Standarnya pun selalu goyah, berubah terus, sehingga apa yang sudah kita kenal pada suatu saat bisa saja tidak mungkin diterapkan untuk menyiasati seni yang baru.(Soedarso, 1990 : 79).

Melihat seni kriya yang berkembang sekarang, kriyawan selain menciptakan karya yang mempunyai fungsi (karya fungsional), juga menciptakan karya - karya yang lebih menekankan pada kreativitas dan bebas untuk berekspresi mengungkapkan ide - ide baru yang bersifat individualistic, dengan adanya teknik seni kriya yang sangat rumit dan membutuhkan ketelatenan, kesabaran, maka ekspresi dalam seni kriya tidaklah dapat serta merta begitu saja keluar dan diwujudkan dengan cepat seperti hanya ekspresi dalam melukis, tetapi ungkapan ekspresi itu di tata, diatur sedemikian rupa sehingga menjadi ungkapan ekspresi yang mempunyai getaran halus.

Untuk melihat posisi seni kriya yang berorientasi pada ekspresi dapat dilihat dalam skema yang dikemukakan oleh SP. Gustami di bawah ini:

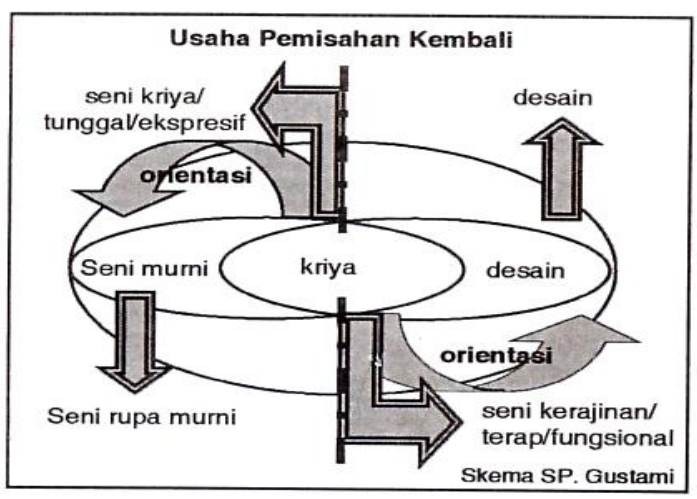

Gambar 1. Skema Oleh SP. Gustami

Diagram diatas menunjukkan usaha baru untuk pemisahan bidang seni kriya, yakni seni kriya yang menekankan segi-segi ekspresi terpisah dengan seni kriya yang lebih berorientasi pada pemenuhan fungsi praktis dalam terminologi seni kerajinan. (SP.Gustami, 2003: 92). Seni kriya yang dalam penciptaannya lebih menekankan ekspresi pribadi akan mengarah pada seni murni yang lebih memperhatikan kaidahkaidah seni rupa modern, sedangkan seni kerajinan dalam penciptaannya lebih mempertimbangkan aspek-aspek disain melalui pemikiran rasional fungsional.

Pada prinsipnya dalam seni kriya bukan merupakan keterpisahaan antara pemikiran rasional fungsional dengan ekspresi estetik melainkan, luluhnya karya cipta kriya yang berbasis pada pemikiran praktis dan kepekaan ekspresi artistik dalam suatu kesatuan yang utuh dan padu. (SP.Gustami 2003 : 93).

Kaitannya dengan karya kriya fungsional, dengan mengutip Viktor Papanek Soedarso Sp. menulis dalam katalog Pameran Kriya Seni 2000, bahwa daerah fungsi yang luas itu menyangkut pula estetika, tentunya continuities akan ada terus kalau saja cita-cita atau pandangan keindahanpun tidak berubah. Seperti diketahui dalam rangka menyelamatkan slogan "Form Follows Function" yang terkenal itu Victor memasukkan enam unsur dalam fungsi, yaitu use, need, method, telesis, aesthetics dan association.(Soedarso, 2000 : 34). Dapat dilihat pada gambar /diagram dibawah ini:

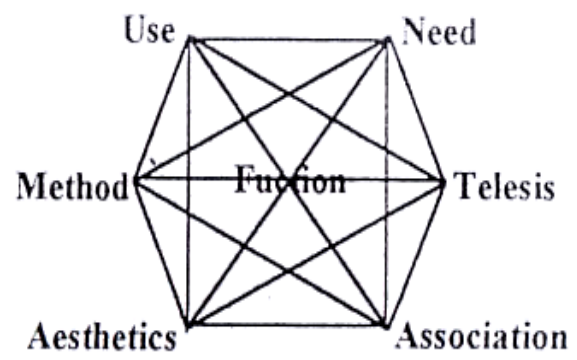

Gambar 2. The Function Complex. (Victor Papanek, $1973: 26$ ). 


\begin{abstract}
Gambar/diagram diatas dapat dijelaskan bahwa dalam menciptakan produk yang fungsional harus
\end{abstract} memperhatikan keenam unsur tersebut Pertama, Method yaitu interaksi antara alat proses dan bahan, penggunaan bahan secara jujur seperti apa adanya, bahan dan alat digunakan secara optimal adalah metode yang baik. Kedua, Use yaitu kegunaan harus sesual dengan fungsinya. Ketiga, Need yaitu kebutuhan sesuai dengan keinginan setepat dan seefisien mungkin. Keempat, Telesis yaitu kandungan dari sebuah disain yang berkaitan dengan cerminan kondisi alam sosial masyarakat dan sejalan dengan tatanan umum dimana ia harus beroperasi. Kelima, Association yaitu pengkondisian psikologis kita yang berhubungan dengan bentuk. Keenam, Aesthetics yaitu yang indah di dalam selera dan seni, sebuah alat untuk membantu mewujudkan bentuk dan warna yang menyenangkan, indah, menarik, penuh kegembiraan, dan bermakna, karena tidak ada tolak ukur yang mudah bagi analisis estetika, hal ini dianggap sebagai ekspresi pribadi.

Perjalanan panjang seni kriya dalam kelangsungan dan perubahannya telah banyak dipengaruhi oleh berbagai faktor baik pekatnya latarbelakang sejarah, luasnya pengalaman teknis dan estetik dan kuatnya interaksi sosial pendukungnya yang sangat berarti bagi perkembangannya.

Kemudian But Muchtar memberikan uraiannya bahwa pada saat sekarang, seni kriya telah memasuki babak baru yakni dengan terjadinya pembagian kriya seperti diuraikan sebagai berikut:

Pada saat ini terdapat dua kategori kriya: yang pertama adalah yang tetap mempertahankan pengertian konvensional, yaitu kriya sebagai objek untuk keperluan seharihari. Para kriyawan kategori ini dengan tekun dan gigih terus mengerjakan barang sebagaimana diwarisi dari leluhura. Ada di antara mereka yang tanpa perubahan sedikitpun, dan ada pula yang berusaha mengembangkannya menjadi lebih bermutu, tergantung dari situasi dan kondisi daerah masing-masing. Kategori yang kedua adalah yang melihat kriya sebagai objek untuk menekankan ekspresi pribadi, sehingga para pembuatnya menamakan dirinya seniman kriya.(But Muhtar, 1991 : 3).

Dalam seni kriya terdapat dua substansi dasar, pada satu sisi seni kriya dapat menjadi seni murni (fine Art) yang mempunyai muatan ekspresi penciptanya, pada sisi lain dapat menjadi pula seni terap (applied art) . Namun dalam mengungkapkan ekspresi terikat oleh bahan dan teknik dalam seni kriya itu sendiri. Dari sini tampak bahwa seni kriya lebih memiliki tingkat kompromis yang tinggi terhadap permasalahan-permasalahan yang rill yang dihadapi senimannya, yaitu tuntutan matenial, teknik, keterdesakan ekonomis di satu sisi dan kesediaannya memberikan sarana penyaluran ide, gagasan, inspirasi dan ekspresi disisi lain. Dengan demikian seni kriya fungsional tetap hidup dengan subur karena memiliki multi fungsi yang dibutuhkan oleh masyarakat, dan seni kriya yang menekankan ekspresi mestinya selalu menata posisinya dengan konsep-konsep penciptaan yang lebih representatif dan dapat dipertanggung jawabkan. Kelebihan inilah yang tarnpaknya telah membuat eksistensi seni kriya semakin kuat di masyarakat.

\section{Penutup}

Dari uraian-uraian yang telah disampaikan, dapat ditarik suatu kesimpulan bahwa seni kriya sebagai media ekspresi perkembangannya mempunyai ruang lingkup yang sangat terbuka, kebebasan, kemampuan, teknik, pengalaman estetik dan kedalaman ekspresi dari senimannya, banyak media yang 
menjadi pilihan seperti kayu, logam, tanah liat, kulit, serat, para kriyawan dapat memanfaatkan sesuai dengan kemampuannya dalam memahami sifatsifat dan karakter bahan, juga kemampuan penguasaan teknik dan skill yang dimiliki.

Dalam seni kriya terdapat dua substansi dasar, pada satu sisi seni kriya dapat menjadi seni tunggal (murni) yang mempunyai muatan ekspresi penciptanya, di sisi lain dapat menjadi seni terap yang lebih menekankan aspek fungsinya. Dimana dalam mengungkapkan ekspresi sangat terikat oleh bahan dan teknik seni kriya yang sangat rumit dan membutuhkan ketelatenan, kesabaran, maka ekspresi dalam seni kriya tidaklah dapat diwujudkan secara cepat tetapi ungkapan ekspresi itu ditata, diatur sedemikian rupa, sehingga menjadi ungkapan ekspresi yang mempunyai getaran halus, yang tentu saja ditunjang dengan kemampuan teknik yang tinggi.

\section{DAFTAR PUSTAKA}

Ahmad Sadali, dalam Agus Sachari (Ed), 1986, Seni, Desain, Teknologi, Kritik, Opini dan Filosofi, Pustaka, Bandung.

Bambang Suwondo, 1979, Sejarah Seni Rupa Indonesia, Proyek dan Penelitian Kebudayaan Daerah, Departemen Pendidikan dan Kebudayaan, Jakarta.

But Muchtar, 1991, "Daya Cipta di Bidang Kriya", SENI, Jurnal Pengetahuan dan Penciptaan Seni, Edisi I / 03 Oktober, B.P. ISI Yogyakarta.

$$
\begin{array}{lr}
\text { Tjetjep Rohendi } & \text { Rohidi, } \\
\text { 2002,"Mempersiapkan } & \text { dan } \\
\text { Mengarahkan Seni Kriya Indonesia } \\
\text { dalam Era Globalisasi yang Terbuka", } \\
\text { Makalah Seminar Internasional Seni } \\
\text { Rupa 2002, PPS. ISI Yogyakarta. }
\end{array}
$$

FX. Mudji Sutrisno Sj.1993, Estetika Filsafat Keindahan, Kanisius, Yogyakarta.

Imam Buchori Zaenuddin, 1999, "Kriya Dalam Wacana Pendidikan Tinggi Menghadapi Budaya Global", Makalah Seminar, STSI Surakarta.

I Made Bandem, 2002, "Mengembangkan Lingkungan Sosial Yang Mendukung Kriya Seni", Makalah Seminar Internasional Seni Rupa, Program Pascasarjana ISI Yogyakarta.

Soedarso Sp., 2006, Trilogi Seni, Penciptaan Eksistensi dan Kegunaan Seni, BP. ISI Yogyakarta.

., 1990, Tinjauan Seni Sebuah Pengantar Untuk Apresiasi Seni, Saku Dayar Sana, Yogyakarta.

2000,"Katalog, Pameran Kriya Seni 2000, Galeri Nasional Indonesia, Jakarta.

1998, "Seni dan Keindahan", Naskah Pidato Pengukuhan Jabatan Guru Besar Tetap Pada Fakultas Seni Rupa, ISI Yogyakarta.

2000, Sejarah Perkembangan Seni Rupa Modern, CV. Studio Delapan Puluh Enterprise, bekerja sama dengan BP. ISI Yogyakarta.

SP. Gustami, 1991, Dampak Modernisasi Terhadap Seni Kriya di Indonesia, Dalam Perkembangan Kesenian Kita, Soedarso Sp. (Ed) BP. ISI Yogyakarta.

SP. Gustami, 2002. "Menetapkan Wacana Seni Kriya Indonesia Sebagai Akar Seni Rupa Indonesia", Makalah Seminar Internasional Seni Rupa, Program Pascasarjana ISI Yogyakarta. 
2000, Seni Kerajinan Mebel Ukir Jepara: Kajian Estetika Melalui Pendekatan Multidisiplin, Penerbit Kanisius, Yogyakarta.

,1991“Seni Kriya Indonesia,

Dilema Pembinaan dan

Pengembangannya, SENI, Jurnal

Pengetahuan dan Penciptaan Seni, Edisi

I/03 Oktober, BP. ISI Yogyakarta.

1990,“Konsep-konsep dibalik

Prodak Kriya Tradisional Indonesia,

Analisis Desain Melalui Pendekatan

Sosial Budaya", Makalah Seminar Kriya

ISI Yogyakarta.

Kriya di Indonesia", dalam Kembang

Setaman, AM. Hermien Kusmayati

(Ed), BP. ISI Yogyakarta.
1997, “Industri Seni Kerajinan

Mebel Ukir Kayu Jepara, Kelangsungan dan Perubahannya", Naskah Pidato

Pengukuhan Jabatan Guru Besar Pada Fakultas Seni Rupa ISI Yogyakarta.

1992, "Filosofi Seni Kriya

Tradisional Indonesia", SENI, Jurnal Pengetahuan dan Penciptaan Seni, Edisi II / 01 Januari, BP. ISI Yogyakarta.

Victor Papanek, 1973, Design for The Real World: Human Ecology and Social

Change, Bantem Books, Toronto, New York.

WJS. Poerwadarminta,1974, Kamus Umum Bahasa Indonesia, PN Balai Pustaka, Jakarta. 